\title{
Releaving Refractory Oxidized Organic Pollutants by Photoelectrochemical Treatment Using Formic ACID as Solvent
}

\author{
Stefan Fränzle \\ Technische Universität Dresden (TUD), International Institute Zittau, \\ Deptm. of Bio- and Environmental Sciences, Markt 23, D-02763 Zittau, FR Germany \\ e-mail: stefan.fraenzle@tu-dresden.de
}

\begin{abstract}
Unlike most organic compounds which undergo ready mineralization on illuminated and oxygenated semiconductors like $\mathrm{TiO}_{2}$, nitroarenes (from dye-, explosives- or polymer production), nitriles or multiply halogenated solvents are inert towards this kind of attack. However, they can be processed if strongly reducing entities are produced in such a semiconductor system. It is shown that the above kinds of refractory pollutants can be treated in formic acid $(\mathrm{HCOOH})$ due to visible irradiation if combined with $\mathrm{W}, \mathrm{Nb}$ or $\mathrm{Bi}$ oxide semiconductor slurries. Toxic functional groups are often removed entirely, e.g. with Hal ( $\neq$ aliph. F), CN whereas nitrobenzenes turn into anilinium ions and benzyl groups undergo rearrangement at $\mathrm{Nb}_{2} \mathrm{O}_{5}$. The method is broadly applicable and cheap.
\end{abstract}

\section{Keywords}

Formic acid; Photoelectrochemical reduction; Decomposition of organic pollutants; Semiconducting oxides; PEC rather than hydrogen storage.

\section{Introduction}

Halocarbons and nitroaromatics, formerly commonly used as solvents or being residues of polymer- or explosive productions (e.g., perchloroethylene, TNT, picrates or toluene diisocyanate) are hard to treat- and refractory residues in the environment. Unlike with other kinds of organics, their oxidation by either direct electron transfer or by using $\mathrm{OH}$ radicals is difficult to impossible. However, hydrogenating enzymes like hydrogenases can process some of these pollutants, and a more convenient reductant can be produced by illuminating a $\mathrm{HCOOH}$ solution ${ }^{1}$ simply subjecting the solvent to photoelectrochemical attack. Previous experiments (Fränzle et al. [4]) dealt with degradation of more complicated aromatic compounds, namely diphenyl amine derivative diclofenac ${ }^{\mathrm{TM}}$ ( $\mathrm{Na}$ salt, readily soluble in $\mathrm{HCOOH}$ ) and its possible fragmentation products like 2,6-dichloroaniline. The purpose of the study (also see Zeisig [10]) reported here was to understand the specific responses and relative reaction kinetics of various functional groups in both aliphatic and aromatic compounds which, unlike diphenyl amines, are very hard to oxidize but might undergo hydrogenation removing the very substituents causing both toxicity and often compromising more classical methods of degradation or mineralization, covering a broad range of moieties in both aliphatic and aromatic organics. This can be done using visible in semiconductors having band gaps near $3 \mathrm{eV}$.

\footnotetext{
${ }^{1} \mathrm{HCOOH}$ is a very polar solvent the physicochemical parameters of which are very similar to those of water. Accordingly, while nitrobenzenes are fully miscible with formic acid, alkanes like hexane or benzene or toluene do not mix in cold, and solubilities of most chlorinated (except for $\mathrm{CH}_{2} \mathrm{Cl}_{2}$ or $\mathrm{CHCl}_{3}$ ) or brominated hydrocarbons in $\mathrm{HCOOH}$ are comparable to those in water.
} 
Theoretical Considerations

Generally speaking, the most likely reducing agent in the conc. $\mathrm{HCOOH}$ medium, namely $\mathrm{CO}_{2}{ }^{-}$could either be produced by direct reduction of $\mathrm{CO}_{2}$ at some $-1.8 \mathrm{~V}$ (Stanbury [9]) or by (anodic- or hole-induced) oxidation of $\mathrm{HCOOH}$ (the structure [more stable tautomer?] of $\mathrm{COOH}$ formed in this manner is unknown while $\mathrm{CO}_{2} \mathrm{H}^{+}$is protonated at oxygen only). Of course, like all simple $\mathrm{C}_{1}$ and $\mathrm{C}_{2}$ compounds and -anions photoelectrochemical as well as electrochemical transformations of $\mathrm{HCOOH}$ were investigated before (e.g. Reichert et al. [8] and quotations in this paper), with a focus on fuel-cell use of formic acid (Okamoto et al. [7]). It turned out that neat $\mathrm{HCOOH}$ cannot be oxidized at Pt anodes without some water being present (ibid.), probably because then there is a stable cover of the electrode surface by CO (with methanol, methyl formate forms instead). The adsorption of $\mathrm{CO}$ to oxide interfaces will be less pronounced than to PGM or gold electrodes, suggesting removal to be easier to accomplish in neat $\mathrm{HCOOH}$ even if the co-processed substrates are not strongly adsorbed.

Semiconductors are solids distinguished by a band gap in between the valence band (-s [several ones except for cubic crystal structures]) and the conduction band; in solution or even some gaseous phase both $\mathrm{e}_{\mathrm{cb}}^{-}$and holes $\left(\mathrm{h}_{\mathrm{vb}}^{+}\right)$can bring about redox reactions with substrates of suitable redox potentials (for 1e-potentials of organics see e.g. Miller et al. [6]). With organics, these agents often cause decay of carbon backbones. Accordingly, key reactions in $\mathrm{HCOOH}$ are:

$$
\begin{gathered}
4 \mathrm{HCOOH}+2 \mathrm{e}_{\mathrm{cb}}^{-} \rightarrow \mathrm{H}_{2} \uparrow+2 \mu-\mathrm{H}(\mathrm{HCOO})_{2}{ }^{-} \\
\mathrm{HCOOH}+\mathrm{h}^{+}{ }_{\mathrm{vb}} \rightarrow \mathrm{HCOO}+\mathrm{H}^{+}{ }_{\text {solv }} \leftrightarrow \mathrm{CO}_{2}^{-}+2 \mathrm{H}^{+} \text {solv }
\end{gathered}
$$

$\mathrm{CO}_{2}{ }^{-}$activity is thus controlled mainly by autoprotolysis or purity of solvent. Unless there is complete cleavage of either kind of charge carriers by dissolved or adsorbed species, like in photochemical solar cells, p-type materials should undergo oxidation with time while in $n$ type solids the anion partial lattice tends to become destroyed and cations get reduced. Unlike the potentials of both conduction and valence band edges, band gaps do not respond to the change of medium unless surface protonation or partial exchange of either cat- or anions take place. The band gaps of the applied semiconductors are given in Tab. 1.

The spectral emission of the used power-LED [(Ga,Al)N] is not very narrow, let alone monochromatic. Absorption of a substantial part of the radiation by each applied semiconductor is likely. There were no attempts to estimate quantum yields as the focus on identifying products and reaction pathways was possibly (and actually) influenced by the kind of semiconductor (rather than its conduction mode). 
Tab. 1: Photophysical data on the semiconductors used in this experimental series

\begin{tabular}{|c|c|c|c|c|}
\hline $\begin{array}{l}\text { Semicon } \\
\text { ductor }\end{array}$ & $\begin{array}{l}\text { Band gap }[\mathrm{eV}] \text {, } \\
\text { conduction } \\
\text { mode }\end{array}$ & $\begin{array}{l}\text { Absorption edge / } \\
\text { spectrum }\end{array}$ & $\begin{array}{l}\text { Theoretical } \\
\text { absorption } \\
\text { edge [nm] }\end{array}$ & Remarks \\
\hline $\mathrm{Bi}_{2} \mathrm{O}_{3}$ & $2.9 ; \mathrm{p}$ & $\begin{array}{l}\text { Indirect transition } \\
\text { near } \quad 414 \quad \mathrm{~nm} \text {; } \\
\text { direct at } \lambda \leq 370 \\
\mathrm{~nm}\end{array}$ & 428 & $\begin{array}{l}\text { BiOX have larger band } \\
\text { gaps. }\end{array}$ \\
\hline $\mathrm{Nb}_{2} \mathrm{O}_{5}$ & $\begin{array}{l}\text { About } 3.2 \text { (see } \\
\text { remarks); } \mathrm{n}\end{array}$ & $\geq 400$ & $390 ?$ & $\begin{array}{l}\text { Data on band gap of } \\
\mathrm{Nb}_{2} \mathrm{O}_{5} \text { do differ } \\
\text { considerably (BG } \approx 3.1- \\
3.8 \mathrm{eV} \text { ); material is not } \\
\text { bright white, suggesting } \\
\mathrm{BG}<\mathrm{BGrutile,} \mathrm{that} \mathrm{is} \mathrm{<} \\
3.1 \mathrm{eV} \text {. Protonated forms, } \\
\text { like alkali niobates, should } \\
\text { have smaller band gaps } \\
\text { (i.e., } \leq 3 \mathrm{eV} \text { ). Nb (and } \\
\text { highest-oxidation state Hf, } \\
\mathrm{W} \text { Ta) oxides are } \\
\text { impossible to dissolve in } \\
\text { acids } \neq \text { HF ("valve } \\
\text { metals"). }\end{array}$ \\
\hline $\mathrm{WO}_{3}$ & $2.8 ; n$ & Some 450 & 443 & $\begin{array}{l}\text { Bright yellow, turns green } \\
\text { upon irradiation in } \\
\text { HCOOH within } 2 \text { min; } \\
\text { tungsten bronzes are } n- \\
\text { type materials also. }\end{array}$ \\
\hline
\end{tabular}

Source: Own

\section{$2 \quad$ Materials and Methods}

- $97 \%$ formic acid (Merck)

- $\mathrm{Bi}_{2} \mathrm{O}_{3}$

- $\mathrm{Nb}_{2} \mathrm{O}_{5}$

- $\mathrm{WO}_{3}$ (all from Sigma-Aldrich)

- $\mathrm{NaBPh}_{4}$ (Fluka)

- Solvents: pentane, hexane

- Substrates: several halogenated hydrocarbons, nitriles and ketones, including

- 1,3-dichloroacetone,

- 1,1,1,2,3,3,3-heptachloropropane,

- highly halogenated ethanes,

- unsaturated chlorohydrocarbons such as chlorobenzene, bromobenzene,

- benzyl chloride, $\mathrm{CClX}=\mathrm{CCl}_{2}(\mathrm{X}=\mathrm{H}$ or $\mathrm{Cl})$,

- 1,2-chlorofluorocyclohexene and -naphthaline,

- $4-\mathrm{Y}-\mathrm{C}_{6} \mathrm{H}_{4}-\mathrm{NO}_{2}(\mathrm{Y}=\mathrm{H}, \mathrm{F} \ldots \mathrm{I}, \mathrm{OH})$,

- nitriles $\mathrm{PhCN}, \mathrm{PhCH}_{2} \mathrm{CN}$, hexane nitrile and 6-bromohexane nitrile.

$2 \mathrm{~g}$ of dried semiconducting oxide are suspended in $20 \mathrm{ml} \mathrm{HCOOH}$ in which $1 \mathrm{mmol}$ of the test compound was dissolved before and irradiated by some blue-emitting high-luminosity 
LED (3.5 W) [Fig. 1] for one hour on a magnetic rotary stirrer ${ }^{2}$ at RT (evaporation hood [HCOOH vapors!]). Due to the kind of the selected light source, heating of the suspension during the experiment is negligible.

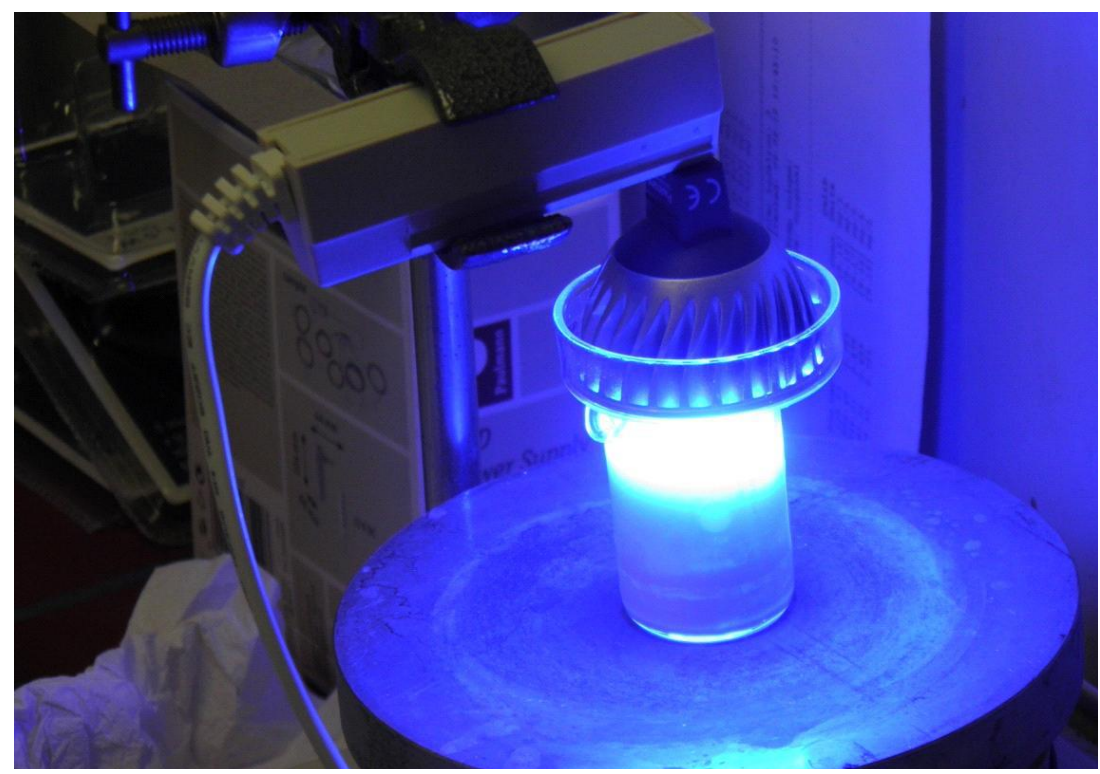

Source: Own

Fig. 1: Blue-light photolysis of some halogenated organic material dissolved in $\mathrm{HCOOH}$ in presence of niobia (stirred off-white $\mathrm{Nb}_{2} \mathrm{O}_{5}$ )

The bright white area in the picture is due to partial over-exposition (light scattered by suspended particles) of the photograph. There is a limited access of air oxygen; the stirred reaction beaker is not completely sealed by the front "window" cover of the LED. Any peroxocarbonate radicals thus forming would reconvert into $\mathrm{CO}_{2}{ }^{-}$by decaying into $\mathrm{OH}$ and $\mathrm{CO}_{3}{ }^{-}$before either reacting with more $\mathrm{HCOOH}$.

Then $1 \mathrm{ml}$ of the solution is taken off and extracted by $1 \mathrm{ml}$ of a $\mathrm{Na}$ tetraphenylborate solution in n-pentane which is not miscible with $\mathrm{HCOOH}$, stirred for $30 \mathrm{~min}$ [Fig. 2] before separating the upper liquid phase.

$20 \mu \mathrm{l}$ of this pentane solution is then injected into an Agilent/Saturn 3000 GC/MS system (temperature range of separation $80-210^{\circ} \mathrm{C}$ ) using a chiral (cyclodextrine-based) column for separation. MS permits identification of products due to fragmentation patterns which is important here as there are some unexpected pathways in the reactions (see below). The traces of $\mathrm{HCOOH}$ passing into the unpolar phase are kept from loading the mass spectrometer by a time lag until switching on of $4.5 \mathrm{~min}$ (then, $\mathrm{T}=116^{\circ} \mathrm{C}$ [slightly above the common $\mathrm{b}$. p. of $\mathrm{HCOOH}])$.

\footnotetext{
${ }^{2}$ As aliphatic CF bonds are not attacked in this system, PTFE coatings of magnetic stirrer bars will not be attacked.
} 


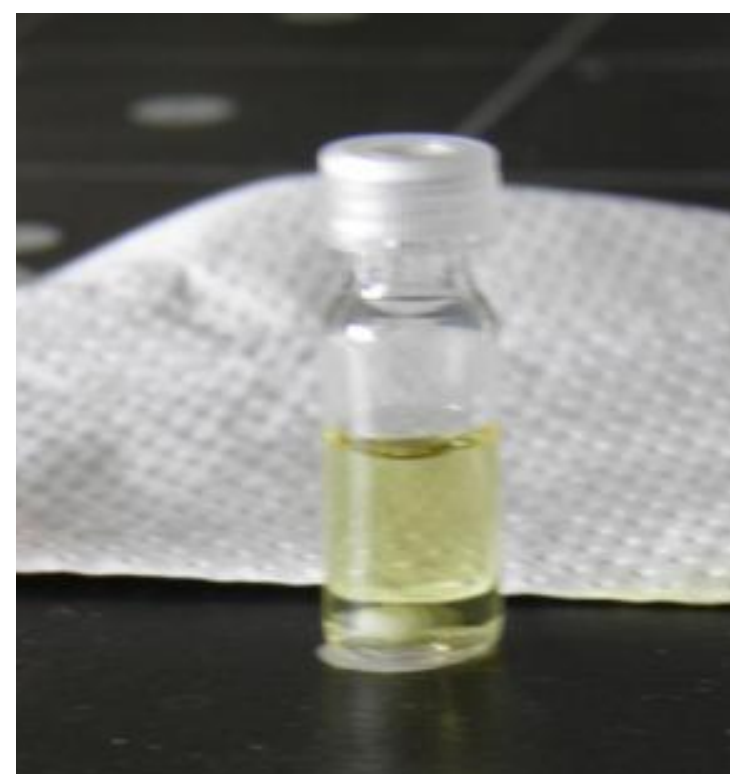

Source: Own

Fig. 2: Extraction of analytes from $\mathrm{HCOOH}$ into n-pentane after irradiation and deposition of the SC particles. The yellow color of the more dense formic acid phase is neither due to remaining nitroaromatics (reduction is complete) nor to metal ion dissolution but points to unidentified red to brownish organic decomposition products.

Of course, doing photoelectrochemistry in aggressive media such as concentrated acids requires that the semiconducting phases be insoluble therein which obviously might pose a problem concerning the SCs fairly commonly employed in PEC, such as pnictides (III-V-SCs like GaP, AlAs, InP) or chalcogenides ( $\mathrm{ZnS}, \mathrm{ZnSe}$, oxides). There even is a paper in the literature describing PEC production of molecular fluorine from anhydrous $\mathrm{HF}$ using $\mathrm{SrTiO}_{3}$; given the rather high solubility of $\mathrm{SrF}_{2}$ and ease of formation of $\mathrm{TiF}_{6}{ }^{2-}$ in this solvent, stability of the photoelectrode is doubtful at best. Considering $\mathrm{HCOOH}$-based media, oxides of valve metals like n-type $\mathrm{WO}_{3}$ and $\mathrm{Nb}_{2} \mathrm{O}_{5}$ and p-type $\mathrm{Bi}_{2} \mathrm{O}_{3}$ fulfill this condition. However, it should be noted that, regardless of high acidity and polarity of $97 \% \mathrm{HCOOH}$, also other SC oxides such as $\mathrm{Fe}_{2} \mathrm{O}_{3}$ do not dissolve in this medium regardless of illumination. In the latter cases, however, effective PEC is unlikely, therefore these systems were no further pursued and investigated.

\section{$3 \quad$ Results}

\subsection{Alterations of Semiconductors}

Upon illumination in $\mathrm{HCOOH}$, yellow $\mathrm{WO}_{3}$ rapidly turns green but never becomes blue; i.e. a tungsten bronze will not form. $\mathrm{Bi}_{2} \mathrm{O}_{3}$ is slowly bleached indicating water uptake to produce $\mathrm{BiO}(\mathrm{OH})$ but no reduction ${ }^{3}$ of $\mathrm{Bi}(\mathrm{III})$ takes place. Otherwise the semiconductors proved stable much beyond expectation (holds for both $\mathrm{n}$ - and p-type materials), also when irradiated much longer (e.g. overnight).

\subsection{Organic Substrates and Products Obtained}

Unlike other compounds insoluble in water, the highly polar (4-substituted) nitrobenzenes do completely mix with $\mathrm{HCOOH}$. There are no intermediate or remanent discolorations

\footnotetext{
${ }^{3} \mathrm{Bi}$ colloids turn green to black; they do readily form in thermochemical reactions with even $\mathrm{CO}$ at $\mathrm{T}<200^{\circ} \mathrm{C}$ and likewise if triplet aromatics form photochemically on $\mathrm{Bi}_{2} \mathrm{O}_{3}$ (Fränzle et al. [3]).
} 
suggesting intermediate formation of nitrosobenzenes, azobenzenes, or aromatic hydroxyl amines. When nitrobenzenes are reduced, one must consider that anilines are fairly strong bases in $\mathrm{HCOOH}$. GC/MS analysis by extraction into pentane thus will occur only if tetraphenylborate assists extraction of the large cation. In addition, an effective extraction can be determined by its by-product in GC/MS; while the aniline (displaying both dehalogenation and nitro group reduction) is directly identified by $\mathrm{MS}$ fragmentation patterns, $\mathrm{BPh}_{4}{ }^{-}$ decomposes right at the injector interface to yield biphenyl already at $\mathrm{T}>130^{\circ} \mathrm{C}$; biphenyl of course produces another distinctive GC/MS signal.

Upon photolysis of the semiconductor slurry/HCOOH/organic pollutant mixture, the probable intermediate $\mathrm{CO}_{2}{ }^{-}$reacts with various organics partly reducing them in this strongly acidic $\left(\mathrm{H}_{0}\right.$ $\approx-3.3$ ) medium, e.g. producing anilinium ions from nitrobenzenes. Functional groups undergoing complete cleavage are:

- cyanogroups from all aliphatic, benzonitriles and benzyl cyanides (phenyl acetonitrile) are completely cleaved, probably forming $\mathrm{HCN}$,

- nitrogroups in nitrobenzenes undergo partial loss of nitro group,

- there is cleavage of methyl or substituted methyl groups of benzyl compounds if irradiated using niobia/HCOOH, e.g. producing some chlorobenzene from benzyl chloride whereas phenyl acetonitrile in the same medium partly rearranges to produce aniline; the fate of exocyclic carbon atoms is unknown so far.

C-halogen bonds do respond differently:

- Aliphatic C-F bonds are not cleaved (a disadvantage in treating CFCs, of course) while aromatic ones do readily react (e.g. 4-fluorophenol, 4-fluoronitrobenzene)

- Both aromatic and aliphatic $\mathrm{C}-\mathrm{Hal}$ bonds $(\mathrm{Hal}=\mathrm{Cl}, \mathrm{Br}$ or $\mathrm{I})$ are cleaved, with

- Reactivity sequence of dechlorination is $-\mathbf{C C l}_{3}<-\mathrm{CHCl}_{2}<-\mathrm{CHalY}$ - or $=\mathrm{CCl}_{2}$, that is, symmetrical 1,1,1,2,3,3,3-heptachloropropane (which, again, is difficult to dissolve in $\mathrm{HCOOH}$ ) does not provide substantial amounts of chiral product on any semiconductor tried; hexachloroethane does only slowly react while pentachloroethane mainly affords 1,1,1,2-tetrachloroethane (plus trichloroethylene) rather than symmetrical tetrachloroethane (for benzyl halogenides see above)

- C-Br bonds, as far as investigated, behave very similarly to $\mathrm{C}-\mathrm{Cl}$ bonds

- Both iodoaliphatics and iodoaromatics produce a dark-colored oily phase which readily separates form $\mathrm{HCOOH}$ but does, however, contain little if any $\mathrm{I}_{2}$

Attempts were done to get a chiral product from processing 1,3-dichloroacetone, racemic 1chloropropanol-2 to be resolved by using a chiral GC-column into two peaks but to no avail: unlike 1-chloroacetone, the above product was not obtained at all, neither was its formate ester. Likewise, other ketones do not undergo hydrogenation, in stark contrast to the (nonPEC) $\mathrm{HCOOH}$-based hydrogenation of immonium ions (Eschweiler-Clarke reaction) or transformations catalyzed by organoiridium complexes splitting $\mathrm{HCOOH}$ into $\mathrm{H}_{2}$ and $\mathrm{CO}_{2}$ (Hull et al. [5]). 
Both cyano- and nitro groups can be completely removed from an organic compound by this reaction. $\mathrm{NO}_{2}$ will then undergo reduction, like nitrate ${ }^{4}$ but unlike $\mathrm{NO}_{2}^{-}$(which is fairly stable in $\mathrm{HCOOH}$ ). The mechanism of cyano group cleavage is unclear; yet it should be noted that a) heating nitriles with oxides such as $\mathrm{CaO}$ causes $\mathrm{CN}$ removal and b) cyanide addition to aldehydes, ketones, imines and the like is reversible. From degradation of phenyl acetonitrile (benzyl cyanide) by $\mathrm{Nb}_{2} \mathrm{O}_{5} / \mathrm{HCOOH} / \mathrm{h} v$, nothing else than toluene and aniline could be obtained by GC/MS.

There are several possible reducing products of $\mathrm{HCOOH}$ when the latter undergo hole oxidation in photoelectrochemistry, including $\mathrm{H}$ atoms, $\mathrm{CO}$, and $\mathrm{CO}_{2}^{-}$. Redox potentials known from aq. solutions can be extrapolated to $\mathrm{HCOOH}$ by a formula from data on redox potentials of many metals and hydrogen in $\mathrm{HCOOH}, \mathrm{HCONH}_{2}$, simple alcohols, $\mathrm{CH}_{3} \mathrm{CN}$, etc. (Fialkov [1]), namely (3):

$$
\varepsilon_{\mathrm{HCOOH}}=0.986 \varepsilon_{\mathrm{H} 2 \mathrm{O}}-0.45
$$

$\mathrm{V}$ vs. NHE in the respective medium is given in Tab. 2 .

Tab. 2: Redox chemistry in various solvents

\begin{tabular}{|l|c|c|}
\hline solvent & a & b \\
\hline water & 1 & 0 \\
\hline $\mathrm{CH}_{3} \mathrm{OH}$ & 0.971 & 0.06 \\
\hline $\mathrm{C}_{2} \mathrm{H}_{5} \mathrm{OH}$ & 0.930 & 0.19 \\
\hline $\mathbf{H C O O H}$ & 0.986 & -0.45 \\
\hline $\mathrm{HCO}-\mathrm{NH}_{2}$ & 0.967 & 0.11 \\
\hline $\mathrm{HCO}-\mathrm{NH}_{2}\left(\mathrm{CH}_{3}\right)$ & 0.899 & -0.12 \\
\hline $\mathrm{CH}_{3} \mathrm{CN}$ & 0.937 & -0.05 \\
\hline neat $\mathrm{N}_{2} \mathrm{H}_{4}$, excluding hydrogen electrode & 0.808 & 1.09 \\
\hline
\end{tabular}

Source: Calculated by this author using data collected by Fialkov [1].

The potential shift $\mathbf{b}$ here depends on basicity of solvent relative to that of water; see $\mathrm{HCOOH}$ vs. $\mathrm{HCONH}_{2}$ and $\mathrm{N}_{2} \mathrm{H}_{4}$ or from phase transfer potentials. Among these, only $\mathrm{H}$ atoms can reduce $\mathrm{Yb}^{3+}$ or $\mathrm{Eu}^{3+}$. There is no color change during PEC (or sonochemical) processing of the system.

Control experiments were done to ascertain that a "live" photoelectrochemical process rather than a catalytic dehalogenating hydrogenation or some based on $\mathrm{HCOOH}$ decomposition ${ }^{5}$ does occur indeed; reductions like those described before were not observed with either stirring the solution in darkness nor using some batch of PEC oxide which had been previously irradiated (cp. the green discoloration of $\mathrm{WO}_{3}$ ) but now exposed to substrate in the dark only. Besides of these control experiments, some by-reactions shows the contribution from hole oxidation of contaminants dissolved in $\mathrm{HCOOH}$ and/or adsorbed to the solid, namely additions of residues from preparing the semiconductors:

\footnotetext{
${ }^{4}$ Dissolving solid silver nitrate in conc. $\mathrm{HCOOH}$ gives rise to a peculiar yet somewhat dangerous kind of clock reaction (Fränzle [2]):

1) there is reduction of nitrate producing mainly $\mathrm{NO}$, then

2) after about $30-50 \mathrm{~s}$ evolution of nitrogen oxides from the meanwhile boiling solution stops, and only then brownish colloidal silver is formed

${ }^{5}$ Both decay pathways of $\mathrm{HCOOH}$ into $\mathrm{CO}$ and water (the dominant and spontaneously occurring one) and into $\mathrm{CO}_{2}$ and $\mathrm{H}_{2}$ (to be catalyzed by iridocene phenanthroline derivative complexes (Hull et al. [5]) are exothermic whereas $\mathrm{HCOOH}$ vapor UV photolysis mainly yields $\mathrm{HCO}$ and $\mathrm{OH}$ radicals
} 
unsaturated aliphatic substrates such as tri- and tetrachloroethylene do not just undergo halogen cleavage but, provided one uses n-type oxides which contain some halide residues from preparation, e.g. $\mathrm{Nb}_{2} \mathrm{O}_{5}$. After short irradiation of a slurry containing niobia and $\mathrm{C}_{2} \mathrm{Cl}_{4}$ in $\mathrm{HCOOH}$, thus some pentachloroethane and hexachloroethane are obtained besides of tri- and dichloroethylene. In $\mathrm{HCOOH}$, both chlorine and bromine, unlike nitrogen oxides or nitrate ion, are unexpectedly metastable, hence will add to a $\mathrm{C}=\mathrm{C}$ double bond rather than oxidize $\mathrm{HCOOH}$ directly if formed from halide ions by photoelectrochemical hole oxidation. Some boiling water extraction of the niobia used here yielded levels of $350 \mu \mathrm{g} / \mathrm{g} \mathrm{Cl}$ and $20 \mu \mathrm{g} / \mathrm{g} \mathrm{F}$, with the common preparation of niobia being hydrolysis (either by liquid water or hot vapor) of $\mathrm{NbCl}_{5}$ produced by either the Kroll process and fractionated distillation/sublimation separation from $\mathrm{Ti}$, Ta etc. or $\mathrm{HCl}$ gas treatment of fluoroniobates. The presence of substantial amounts of fluoride in the samples argues for the latter method of preparation; absence of CFCs from the product mixture obtained from $\mathrm{C}_{2} \mathrm{Cl}_{4}$ or $\mathrm{C}_{2} \mathrm{HCl}_{3}$ can be accounted for as the holes do not directly oxidize $\mathrm{C}=\mathrm{C}$ double bonds nor fluoride ion, that is:

$$
2 \mathrm{Cl}_{-\mathrm{ad}} \mathrm{S} \rightarrow \mathrm{Cl}_{2}^{-} \text {, no } \mathrm{FY}^{-} \text {species } \rightarrow \text { chlorination of } \mathrm{C}=\mathrm{C} \text { bonds only }
$$

no fluorine introduced; $\mathrm{k}_{\mathrm{Cl} 2-/ \mathrm{C}=\mathrm{C}}>>\mathrm{k}_{-\mathrm{Cl}}$ in $\mathrm{C}_{2} \mathrm{Cl}_{4}$

\section{Conclusion}

The broad range of organic compounds which are very difficult to oxidize by either valence band holes, $\mathrm{OH}$ radicals or anodes, however, undergo the process described here, and the various possible chemical/technical origins of these suggest to use them in remediation of residues especially as $\mathrm{HCOOH}$ is cheap and products, some of which are toxic still, like anilines, are then much more accessible towards microbiological secondary treatment. The cleavage of cyano groups and of exocyclic benzylic $\mathrm{C}$ atoms (cp. indanes) in the $\mathrm{HCOOH} /$ niobia system could probably be used in preparative organic chemistry, e.g. that of alcohols and (chiral) phenyl propanoic- or -acetic acids.

\section{Literature}

[1] FIALKOV, Y. Y.: Nicht nur im Wasser. Deutscher Verlag für Grundstoffindustrie, Leipzig, 1979. Bestell-Nr.: 541525 0. No ISBN (no longer in print or sold). DOI: $10.1002 /$ zfch.19800200235.

[2] FRÄNZLE, S.: Photochemischer Ligandenaustausch auf Halbleiterkolloiden und in Ionenpaaren zur Carbonylierung und Synthese neuer CO-haltiger Thiocyanatokomplexe von Os(II), Os(III), Ir(III) und Mo(III) als Beitrag zum Verständnis bindungsisomeren Verhaltens. PhD thesis; Kiel University, 1992.

[3] FRÄNZLE, S.; KAYSER, G.; LIEPEL, T. G.; SONNTAG, S.; HOFRICHTER, M., MARKERT, B.: Photochemischer Abbau von PAK in Bismutoxid-Suspensionen durch Metallkomplexe und Luftsauerstoff. Poster presented at Vortragstagung of GDChFachgruppe Photochemie. Mülheim/Ruhr, April 7th - 9th, 2003.

[4] FRÄNZLE, S., SILBERNAGEL, H., UCHLIER, L., LIEPELT, G.: Environmental chemistry at activated interfaces - then and now. Chemia i Inźyniernia Ecologićzna. Ecological Chemistry and Engineering. Opole, 2010, Volume 17, pp. 16-25. ISSN 1231-7098. 
[5] HULL, J. F.; HIMEDA, Y.; WANG, W.-H.; HASHIGUCHI, B.; PENANA, R.; SZALDA, D. J.; MUCKERMAN, J. T.; FUJITA, E.: Reversible hydrogen storage using $\mathrm{CO}_{2}$ and a proton-switchable iridium catalyst in aqueous media under mild temperatures and pressures. Nature Chemistry. 2012, Volume 4, pp. 383-388. DOI: $\underline{10.1038 / \mathrm{NCHEM} .1295}$.

[6] MilleR, L. L.; NORDBlOM, G. D.; MAYEDA, E. A.: Simple, comprehensive correlation of organic oxidation and ionization potentials. The Journal of Organic Chemistry. 1972, Volume 37, Issue 6, pp. 916-918. DOI: 10.1021/jo00971a023.

[7] OKAMOTO, H.; GOJUKI, T.; OKANO, N.; KUGE, T.; MORITA, M.; MARUYAMA, A.; MUKOUYAMA, Y.: Oxidation of formic acid and methanol and their potential oscillations under no or little water conditions. Electrochimica Acta. 2014, Volume 136, pp. 385-395. DOI: 10.1016/j.electacta.2014.05.135.

[8] REICHERT, R.; ZAMBRZYCKI, C.; JUSYS, Z.; BEHM, R. J.: Photo-electrochemical oxidation of organic $\mathrm{C} 1$ molecules over $\mathrm{WO}_{3}$ films in aqueous electrolyte: competition between water oxidation and C1 oxidation. ChemSusChem. 2015, Volume 8, Issue 21, pp. 3677-3687. PMID 26382643. DOI: $10.1002 /$ cssc.201500800.

[9] STANBURY, D. M.: Reduction Potentials Involving Inorganic Free Radicals in Aqueous Solution. Advances in Inorganic Chemistry. 1989, Volume 33, pp. 69-138. DOI: $10.1016 / \mathrm{S} 0898-8838(08) 60194-4$.

[10] ZEISIG, C.: Master thesis. IHI Zittau, 2013. 


\section{OSVĚTLENÉ SUSPENZE POLOVODIČŮ V KYSELINĚ MRAVENČÍ: MOŽNOSTI FOTOCHEMICKO-REDUKTIVNIIHO ODBOURÁVÁNÍ HALOGENIZOVANÝCH, NITROVANÝCH ŠKODLIVIN A JINÝCH CHEMIKÁLIÍ}

Na rozdíl od většiny organických sloučenin, které procházejí připravenou mineralizací na osvětlených a okysličených polovodičích, jako je $\mathrm{TiO}_{2}$, nitroareny (z výroby barviv, exploziv či polymerní produkce), nitrily nebo halogenová rozpouštědla s násobnou vazbou jsou vůči tomuto druhu ataku inertní. Nicméně mohou být zpracovány v př́ípadě, kdy silně redukční entity jsou vyráběny $\mathrm{v}$ polovodičovém systému. Je zrrejmé, že výše uvedené druhy žáruvzdorných znečišt'ujících látek lze zpracovávat pomocí kyseliny mravenčí (HCOOH) $\mathrm{v}$ suspenzi polovodivých oxidů, a to vzhledem $\mathrm{k}$ viditelné iradiaci v kombinaci $\mathrm{s} \mathrm{W}, \mathrm{Nb}$ nebo Bi. Toxické funkční skupiny jsou často zcela odstraněny, např. Hal ( $\neq$ alif. F), zatímco $\mathrm{CN}$ nitrobenzeny se promění na ionty anilinia a benzylové skupiny se přeskupí na $\mathrm{Nb}_{2} \mathrm{O}_{5}$. Tato metoda je široce použitelná a levná.

\section{BELICHTETE HALBLEITERSUSPENSIONEN IN AMEISENSÄURE: MÖGLICHKEITEN ZUM PHOTOCHEMISCH-REDUKTIVEN ABBAU HALOGENIERTER, NITRIERTER SCHADSTOFFE U.A. CHEMIKALIEN}

Während die meisten Organika an belichtetem und belüftetem $\mathrm{TiO}_{2}$ photochemisch glatt mineralisiert werden, sind Nitroaromaten (aus der Herstellung von Farben, Sprengstoffen oder Polymeren), Nitrile und halogenierte Lösungsmittel in dieser Hinsicht inert. Sie reagieren allerdings dann, wenn in einem solchen Halbleitersystem stark reduzierende Intermediate freigesetzt werden. Daher sind die obigen refraktären Schadstoffe in Ameisensäure $(\mathrm{HCOOH})$ gelöst an Suspensionen halbleitender Oxide von $\mathrm{W}, \mathrm{Nb}$ oder $\mathrm{Bi}$ mit sichtbarem Licht abbaubar. Funktionelle Gruppen wie Hal ( $\neq$ aliph. F), CN werden vollständig abgespalten, Nitrobenzole zu Aniliniumsalzen reduziert, während Benzylgruppen an $\mathrm{Nb}_{2} \mathrm{O}_{5}$ umgelagert werden. Die Methode ist preisgünstig und auf sehr unterschiedliche Stoffe anwendbar.

\section{OŚWIETLONE ZAWIESINY PÓŁPRZEWODNIKÓW W KWASIE MRÓWKOWYM: MOŻLIWOŚCI FOTOCHEMICZNEGO REDUKUJĄCEGO WYTRĄCANIA HALOGENIZOWANYCH, NITROWANYCH SUBSTANCJI SZKODLIWYCH I INNYCH SUBSTANCJI CHEMICZNYCH}

W odróżnieniu od większości związków organicznych, które łatwo dają się mineralizować na oświetlonych i utlenionych półprzewodnikach, takich jak $\mathrm{TiO}_{2}$, nitroaromaty (z produkcji barwników, materiałów wybuchowych lub polimerów), nitryle lub halogenowe rozpuszczalniki z układami wielokrotnych wiązań są wobec nich obojętne. Niemniej jednak mogą być przetwarzane w sytuacji, gdy dodane zostaną mocno redukujące produkty pośrednie. Dzięki temu wymienione odporne substancje szkodliwe rozpuszczone w kwasie mrówkowym $(\mathrm{HCOOH})$ w zawiesinie tlenków półprzewodnikowych $\mathrm{W}$, Nb lub Bi rozkładają się w świetle widzialnym. Grupy funkcyjne, takie jak Hal ( $\neq$ alif. F), CN zostają całkowicie usunięte, nitrobenzeny przekształcają się $\mathrm{w}$ anilinę a grupy benzylowe przegrupowują się $\mathrm{w}$ $\mathrm{Nb}_{2} \mathrm{O}_{5}$. Metoda jest tania i może mieć zastosowanie do wielu materiałów. 